\title{
Submarine Groundwater Discharge to a High-Energy Surf Zone at Stinson Beach, California, Estimated Using Radium Isotopes
}

\author{
Nicholas R. de Sieyes • Kevan M. Yamahara • \\ Adina Paytan - Alexandria B. Boehm
}

Received: 13 October 2009 /Revised: 19 January 2010 /Accepted: 18 April 2010 / Published online: 29 May 2010

(C) The Author(s) 2010. This article is published with open access at Springerlink.com

\begin{abstract}
Two 14-day experiments conducted in the dry summer (July 2006) and wet winter (March 2007) seasons, respectively, examined tidal, wave-driven, and seasonal variability of submarine groundwater discharge (SGD) at Stinson Beach, CA, using natural radium tracers. Tide stage, tide range, breaker height, and season each explained a significant degree of radium variability in the surf zone. A mass balance of excess radium in the surf zone was used to estimate SGD for each season, confirming larger discharge rates during the wet season. Our results indicate median groundwater discharge rates of 6 to $8 \mathrm{~L} \mathrm{~min}^{-1} \mathrm{~m}^{-1}$ in July 2006 and 38 to $43 \mathrm{~L} \mathrm{~min}^{-1} \mathrm{~m}^{-1}$ in March 2007. SGD from $200 \mathrm{~m}$ of Stinson Beach in March 2007 contributed a flux of phosphate and dissolved inorganic nitrogen approximately equal to that associated with all local creeks and streams within $6 \mathrm{~km}$ of the study site at that time.
\end{abstract}

Keywords Submarine groundwater discharge - Radium . Nutrient flux · California coast

\section{Introduction}

Submarine groundwater discharge (SGD) is well documented as an important source of inorganic, organic, and microbial

N. R. de Sieyes $(\square) \cdot$ K. M. Yamahara $\cdot$ A. B. Boehm Environmental Water Studies, Department of Civil and Environmental Engineering, Stanford University, Stanford, CA 94305, USA

e-mail: desieyes@stanford.edu

\section{A. Paytan}

Institute of Marine Sciences, Earth \& Planetary Sciences

Department, University of California Santa Cruz,

Santa Cruz, CA 95064, USA pollutants to the coastal ocean (Boehm et al. 2004; Bone et al. 2007; Santos et al. 2008). Numerous physical forcing mechanisms including meteoric hydraulic head, tide and wave pumping, seasonal precipitation/evapotranspiration cycles, and variations in groundwater density force the flow of groundwater to the ocean (Burnett et al. 2006). Due to interactions between multiple forcing mechanisms at any given location and time, SGD is temporally and spatially variable. Site-specific studies are often required to fully understand the timing, magnitude, and importance of SGD in a given region.

Many of the mechanisms that modulate SGD have been investigated numerically and through field studies. Tidal pumping has been explored on both the semidiurnal (AtaieAshtiani et al. 1999; Robinson et al. 2007) and fortnightly spring-neap timescales (Boehm et al. 2004; de Sieyes et al. 2008; Kim and Hwang 2002; Santos et al. 2009; Taniguchi 2002). Michael et al. (2005) documented a large, seasonally variable component of SGD controlled by precipitation/ evapotranspiration cycles. Wave setup and run-up from breaking waves influence beach water table dynamics and drive SGD at coastal margins (King et al. 2009; Li et al. 2004; Longuet-Higgins 1983). However, breaking waves make direct discharge measurement by seepage meter impossible (Burnett et al. 2006; Huettel et al. 1996; Libelo and McIntyre 1994). This presents a unique challenge in studying SGD along coastlines with high wave energy where wave-driven SGD may be most important. In such environments, it is often necessary to estimate SGD by indirect techniques, such as those based on chemical tracers.

This study explores SGD variability at multiple timescales using naturally occurring radium isotopes as tracers of groundwater discharge. Moore and collaborators pioneered the use of the quartet of naturally occurring radium 
isotopes, which vary in half-life from 3.7 days to 1,600 years, as tracers for ocean mixing and groundwater input to coastal systems (Krest and Harvey 2003; Moore 1997, 2003). The divalent radium cation is bound to soil particles and rocks in freshwater but readily desorbs via ion exchange in the presence of high ionic strength solutions (Elsinger and Moore 1980). Accordingly, in coastal aquifers where saline groundwater mixes with fresh groundwater, high radium waters result. Open seawater is relatively radium deplete; therefore, radium activity above that of open seawater suggests a coastal source that in many cases is groundwater. Because radium isotopes behave conservatively in the nearshore after accounting for radioactive decay, the radium quartet is useful for characterizing ocean mixing and rates of submarine groundwater discharge (Charette et al. 2001; Moore 1996, 1999, 2000a, b, 2003).

The present study uses the two short-lived radium isotopes ${ }^{223} \mathrm{Ra}\left(t_{1 / 2}=11\right.$ days $)$ and ${ }^{224} \mathrm{Ra}\left(t_{1 / 2}=3.6\right.$ days $)$ and the long-lived isotope ${ }^{226} \mathrm{Ra}\left(t_{1 / 2}=1,600\right.$ years $)$ to investigate how SGD at a wave-dominated California beach is modulated by semidiurnal tides, fortnightly neap-spring tides, swell events, and the seasonal precipitation cycle. The work was conducted at Stinson Beach, a small beach community north of San Francisco, CA, USA. Groundwater at the site is contaminated with nitrogen (nitrate and ammonium, primarily), orthophosphate, and human fecal bacteria from septic systems, and previous research at the site has documented nutrification of the nearshore coastal ocean by fresh SGD in the summer (de Sieyes et al. 2008). A previous experiment at this beach during dry summer weather estimated SGD using salinity as a groundwater tracer (de Sieyes et al. 2008). The present study builds on that previous study but uses an entirely new radium tracer dataset consisting of over 500 measurements to investigate the effects of waves, tides, and season on SGD.

\section{Methods and Materials}

Study Site Stinson Beach (Fig. 1) is an open ocean, southwest facing, reflective beach with mixed semidiurnal tides, a spring tide range of 2.0 to $2.5 \mathrm{~m}$, and a high-energy surf zone. Breakers with heights typically in the range of 0.5 to $2 \mathrm{~m}$ result primarily from northwest swells during winter and a combination of northwest and south swells in summer. A short description of local hydrogeology and human development in the area can be found elsewhere (de Sieyes et al. 2008). Our research site is focused on the beach at the end of Calle de Resaca, a residential street in downtown Stinson Beach (37.899 N, 122.646 W; Fig. 1).

The climate at Stinson Beach is Mediterranean with an annual average rainfall of 60 to $120 \mathrm{~cm}$ occurring predominately between October and April (Stinson Beach

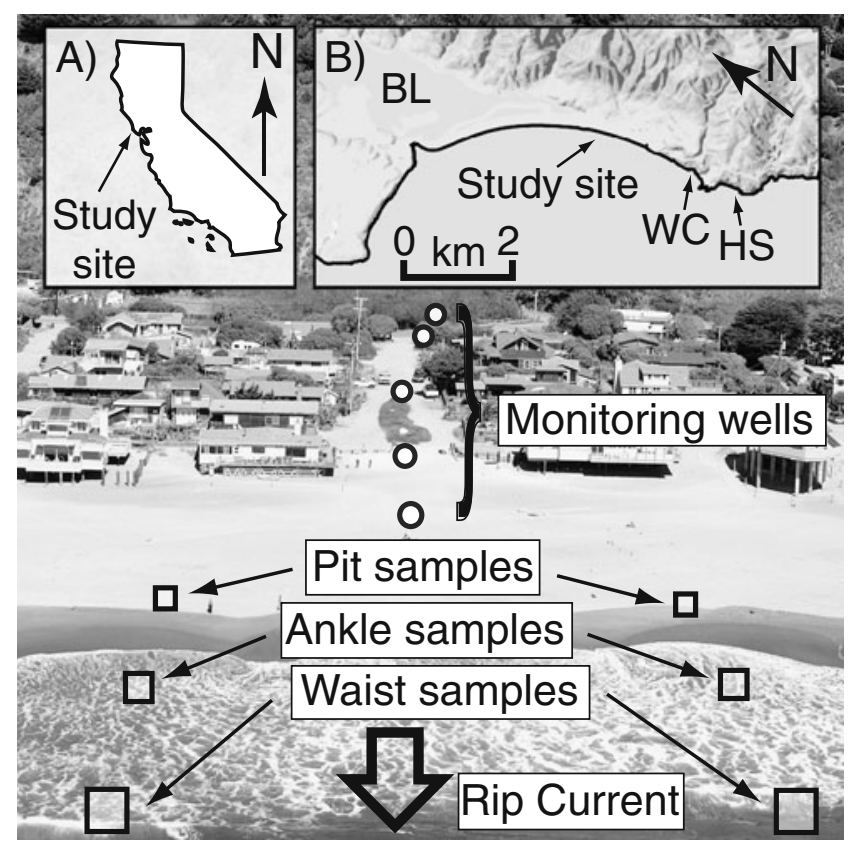

Fig. 1 Sampling locations at Stinson Beach. $A$ Location of Stinson Beach within California. $B$ The location of the Calle de Resaca field site with respect to Bolinas Lagoon $(B L)$, Webb Creek $(W C)$, and the hot spring (HS). In the main figure, the locations of ankle, waist, and pit samples, as are the monitoring wells and location of the rip current flowing between the two surf zone transects. Offshore sampling locations are not shown but are given within the text. See houses for approximate scale. Aerial photograph copyright (C) 2002-2009 Kenneth \& Gabrielle Adelman, California Coastal Records Project, www.californiacoastline.org

County Water District 1998). During the dry season, Bolinas Lagoon (37.908 N, $122.682 \mathrm{~W})$ and a local coastal hot spring $(37.886 \mathrm{~N}, 122.630 \mathrm{~W})$, are the only other potential sources of radium within $20 \mathrm{~km}$ of the study site (Fig. 1). Numerous ephemeral creeks deliver freshwater to the coastal ocean during the wet season but generally run dry by late summer (Stinson Beach County Water District 1998). Only Webb Creek (37.885 N, 122.629 W) discharges directly to the nearshore within $7 \mathrm{~km}$ of the site; all other creeks discharge to Bolinas Lagoon (Fig. 1).

Radium activities in the surf zone were monitored over semidiurnal and spring-neap tidal cycles during both the dry and rainy seasons. Fourteen-day experiments were conducted from 14 through 28 July 2006 and from 10 through 24 March 2007. During each study, neap tide (17 July 2006 and 11 March 2007, respectively) preceded the spring tide (24 July 2006 and 18 March 2007, respectively).

Tide, Wave, and Beach Conditions Tide elevation measurements were obtained from a NOAA tide gauge at Point Reyes, approximately $30 \mathrm{~km}$ from Stinson Beach (http:// tidesandcurrents.noaa.gov, Station ID 9415020, $38.00 \mathrm{~N}$, $122.98 \mathrm{~W}$ ). Tides along this coast are in phase at a spatial scale of $30 \mathrm{~km}$, so this tide gauge gives excellent tide data 
for Stinson Beach. Data were recorded at 6-min intervals. Daily tidal range was calculated from daily maxima and minima. We define spring and neap tide as those days during the tidal cycle when tidal range is maximal and minimal, respectively.

Wave measurements were obtained from National Buoy Data Center buoy \#46026 at San Francisco (http://www. ndbc.noaa.gov, $37.759 \mathrm{~N} 122.833 \mathrm{~W}$ ), the closest directional wave buoy to the site. The buoy is located in $55 \mathrm{~m}$ of water $23 \mathrm{~km}$ due southwest (offshore) from the site. Spectral wave data were recorded at 1-h intervals.

A continuous record of surf zone breaker height was estimated from significant wave height and period for the duration of our study using the method of Komar (1998). This calculation assumes that wave energy is conserved from deep water to the surf zone and ignores the effects of refractive focusing, diffraction, bottom friction, currents, and wave-wave interactions. Stinson Beach lies in the wave shadow of nearby Bolinas Point and Duxbury Reef, so a correction factor was necessary to increase the accuracy of the breaker height predictions. Seven synoptic breaker height observations were made in the field using surfers riding breaking waves as benchmarks, a commonly used method for estimating breaker height (Caldwell 2005). These observations were compared to the continuous time series, and a correction factor was derived using linear regression. The Komar-estimated significant wave heights were multiplied by the correction factor to obtain a continuous time series of significant breaker heights. These data are used to explore correlative relationships between waves and SGD.

During each study, the surf zone was viewed from a high vantage point above the beach, and rip cell spacing was estimated using a georeferenced map. Beach topography was also surveyed during each study by standard methods using a scope and stick (Fig. 2).

Water Sampling The tidal regime at Stinson Beach is mixed semidiurnal. To characterize tidal variation in radium activities, we sampled the surf zone at high-high and lowlow tide along two cross-shore transects approximately every other day of each study. The two transects were located $100 \mathrm{~m}$ apart in the alongshore direction and extending from the water line out into the surf zone (Fig. 1). During both studies, the two sampling transects straddled a rip current, indicating that the two transects sampled distinct rip cells. Local knowledge of the site coupled with aerial observations from a high vantage point during each study confirmed the permanence of the rip cell location. During each sampling at the site, surf zone samples were collected along each transect at 0.2 and $0.7 \mathrm{~m}$ water depths referred to as "ankle" and "waist depths", respectively (Fig. 2). These depths occurred well
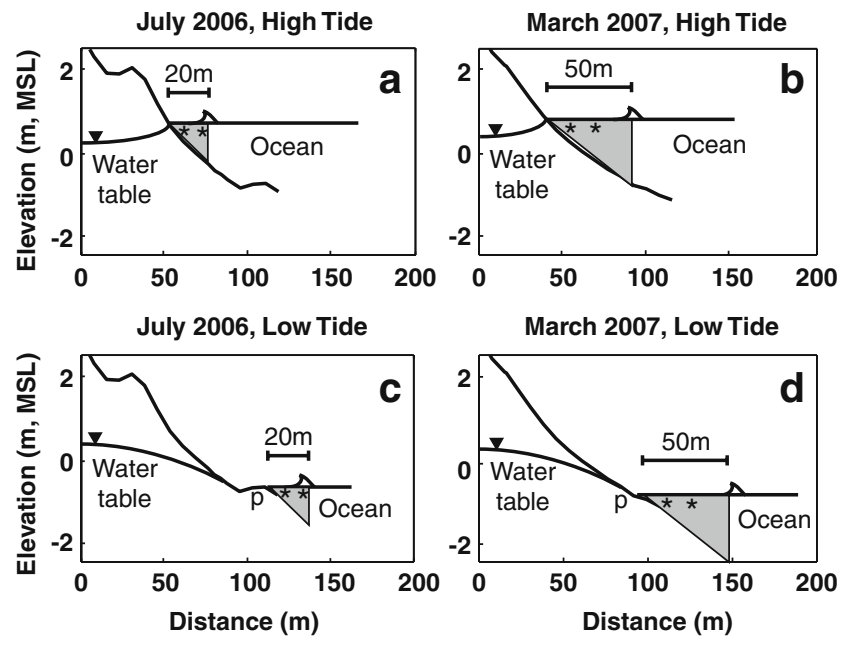

Fig. 2 Diagram showing beach topography and the geometry of the surf zone box with sampling locations for July 2006 at high tide (a), March 2007 at high tide (b), July 2006 at low tide (c), and March 2007 at low tide (d). In each panel, the ocean is shown on the right side and the beach on the left side. Beach topography from surveys made with scope and stick is shown in meters relative to mean sea level on the $y$-axis and in meters relative to a known permanent datum on the $x$-axis. The geometry of the surf zone box is shown as a gray prism. Breaking wave symbols delineate the outer limits of the surf zone box, and the surf zone width in meters is shown for each experiment. The approximate locations of the ankle and waist depths are shown as asterisks, and the approximate locations of pit samples collected at low tides are shown with the letter " $p$ "

within the surf zone. Although a small sand bar was observed during each experiment, no distinct break was ever noted between an inner and outer surf zone at the site. In order to standardize sample collection depth, 0.2 and $0.7 \mathrm{~m}$ heights were noted on the legs of the two individuals who conducted all surf zone sampling. During sample collection, care was taken to collect a mixture of water from the entire water column from surface to sandy bottom. For the surf zone, $n_{\mathrm{Jul} 06}=42$ and $n_{\mathrm{Mar} 07}=32$.

At low-low tides only, groundwater immediately adjacent to the water line was sampled from shallow pits dug into the beach approximately $10 \mathrm{~m}$ back from the water line $\left(n_{\mathrm{Jul06}}=18\right.$ and $n_{\mathrm{Mar} 07}=14$; Fig. 2$)$. In addition, subaerial seepage faces were sampled when they developed at the lowest tides $\left(n_{\mathrm{Ju} 106}=17\right.$ and $\left.n_{\mathrm{Mar} 07}=2\right)$. On multiple days during each experiment, groundwater was sampled from temporary stainless steel drive-point piezometers installed into the top $2 \mathrm{~m}$ of the water table just above the high tide berm $\left(n_{\mathrm{Ju} 106}=1\right.$ and $\left.n_{\mathrm{Mar} 07}=5\right)$.

To characterize offshore waters during neap and spring tide, surface offshore ocean water samples were obtained 180,870 , and $1,615 \mathrm{~m}$ from the beach along a cross-shore transect on the days of the third quarter and new moons during each experiment (Fig. 3).

The ebb flow from Bolinas Lagoon $(37.908 \mathrm{~N}$, $122.682 \mathrm{~W}$ ) was sampled every 2 to 4 days during both 

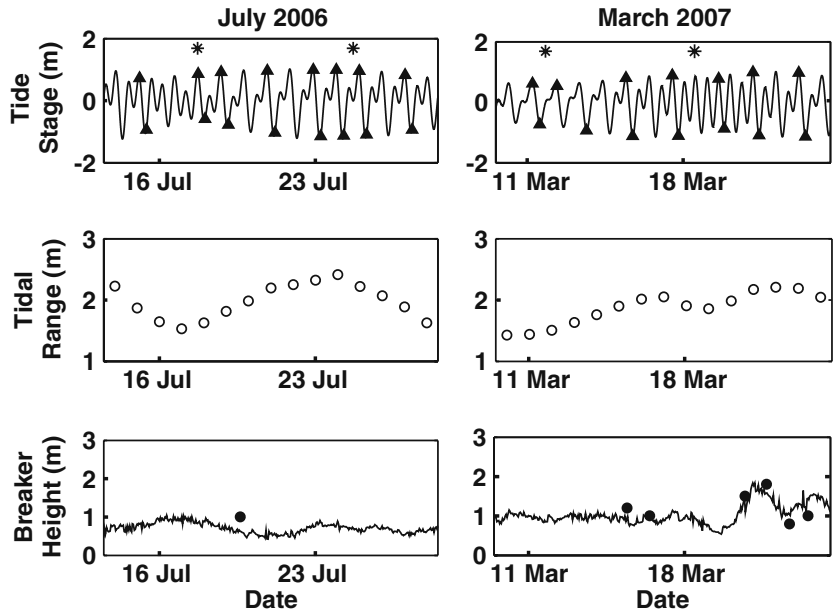

Fig. 3 Tidal stage (meters) relative to mean sea level, daily tidal range (meters), and corrected breaker heights for both the July 2006 and March 2007 studies. In the tidal record insets (top), the timing and tide stage during surf zone sampling events are shown as filled triangles and the timing of offshore sampling events on the days of the third quarter and new moons are shown as asterisks. In the breaker height insets, breaker observations from the field are shown as filled circles, and the corrected, continuous record calculated using San Francisco buoy data is shown as a black line

studies $\left(n_{\mathrm{Jul06}}=4\right.$ and $\left.n_{\mathrm{Mar} 07}=7\right)$. The hot spring $(37.886 \mathrm{~N}$, $122.630 \mathrm{~W}$ ) was sampled on 19 March 2007.

Clean, triple-rinsed 20-L collapsible low-density polyethylene containers were used for water collection. For a given water sample, a total of approximately $100 \mathrm{~L}$ was composited. A 1-L subsample was collected into a clean triple-rinsed bottle and used for all nonradium chemical analyses. All samples were analyzed for ${ }^{223} \mathrm{Ra}$ and ${ }^{224} \mathrm{Ra}$. A subset of samples was analyzed for ${ }^{226} \mathrm{Ra}$ including pits, seeps, offshore, Bolinas Lagoon, hot spring, and a subset of monitoring wells. In addition, surf zone samples collected at the high and low tide closest in time to the offshore sampling events during each experiment were analyzed for ${ }^{226} \mathrm{Ra}$.

Creek Survey On 16 and 17 March 2007, creeks flowing within $6 \mathrm{~km}$ of the site were surveyed for flow rate and nutrient concentration to provide estimates of creek-associated nutrient flux to the local coastal ocean. The survey included creeks flowing to Bolinas Lagoon $(n=11)$ as well as those discharging directly to the ocean $(n=1)$. Little to no creek discharge occurs during late summer at the site, precluding a similar survey during July 2006. First-order estimates of flow rate in each creek were measured via the float method (Weight and Sonderegger 2001) whereby velocity is measured by timing the travel of a float down a straight reach of a creek. Measurements were made following USGS guidelines as outlined in Rantz (1982). Surface velocities were converted to a depth-averaged velocity using a correction factor of 0.85 and multiplied by cross-sectional area to calculate flow rate. Reflecting the order-of-magnitude nature of our measurements, we conservatively assume $25 \%$ standard deviation associated with these flow rate measurements (Rantz 1982). Estimates of creek-associated nutrient flux were calculated by multiplying nutrient concentration by flow rate. Standard deviations of nutrient flux are calculated by propagating standard deviations of nutrient concentration and flow rates.

Nutrient Analysis The concentrations of orthophosphate, silicate, and dissolved inorganic nitrogen were previously reported for all July 2006 water samples in de Sieyes et al. (2008). During the March experiment, a 30-mL aliquot of water was $0.2 \mu \mathrm{m}$ PES filtered (Millipore, Billerica, MA, USA) and stored at $-20^{\circ} \mathrm{C}$ for nutrient analyses. The concentrations of orthophosphate, silicate, nitrate, nitrite, and ammonium were measured by standard methods with a nutrient autoanalyzer (Lachat QuikChem 8000, Loveland, CO, USA). Detection limits are $0.2 \mu \mathrm{M}$ nitrate, $0.1 \mu \mathrm{M}$ nitrite, $0.1 \mu \mathrm{M}$ phosphate, $1.0 \mu \mathrm{M}$ silicate, and $0.1 \mu \mathrm{M}$ ammonium. Dissolved inorganic nitrogen is reported as the sum of nitrate, nitrite, and ammonium. Five percent of nutrient samples were analyzed in duplicate, and standard deviation was $<5 \%$ for each analyte.

Radium Analysis Dissolved radium was extracted from $\sim 100 \mathrm{~L}$ water samples in the field by filtering through columns of $\mathrm{MnO}_{2}$-impregnated acrylic fiber at a flow rate not exceeding $1 \mathrm{~L} \mathrm{~min}^{-1}$ (Moore and Arnold 1996; Rama et al. 1987). Untreated acrylic fiber plugs were used to prevent the contamination of the $\mathrm{MnO}_{2}$ fiber by particulates. The fibers were removed from the columns and stored in plastic bags until processing, at which time they were rinsed with deionized water and hand-squeezed to remove excess water. Activities of the short-lived isotopes ${ }^{223} \mathrm{Ra}$ and ${ }^{224} \mathrm{Ra}$ were measured within 3 days of collection using a delayed coincidence counter (Moore 2003; Moore and Arnold 1996). Errors associated with radium analysis via this method are 10\% (Moore 2003). Samples were not reanalyzed after collection to quantify ${ }^{228} \mathrm{Th}$-supported ${ }^{224} \mathrm{Ra}$ activity. However, samples collected during subsequent experiments at the Stinson Beach site showed that ${ }^{228} \mathrm{Th}$ supported ${ }^{224} \mathrm{Ra}$ activity accounts for approximately $3 \%$ or less of the original ${ }^{224}$ Ra activity (Black et al. 2009; Rama et al. 1987). Because ${ }^{228} \mathrm{Th}$-supported ${ }^{224} \mathrm{Ra}$ activity at the site is small compared to the error associated with the ${ }^{224} \mathrm{Ra}$ method, we assume for the purposes of this paper that all ${ }^{224} \mathrm{Ra}$ in samples are excess ${ }^{224} \mathrm{Ra}$, i.e., ${ }^{224} \mathrm{Ra}$ unsupported by ${ }^{228} \mathrm{Th}$ decay in the sample.

${ }^{226} \mathrm{Ra}$ activity was measured via its ${ }^{218} \mathrm{Po}$ daughter following Kim et al. (2001). Mn-impregnated fibers were aged for at least 6 months to allow for decay of the shortlived isotopes. Fibers were then moistened with deionized water to obtain constant recoil efficiency, sealed in an air- 
tight helium-flushed glass tube, and incubated for at least 3 weeks to allow in-growth of ${ }^{222} \mathrm{Rn}$ daughter product to reach activities within $0.1 \%$ of secular equilibrium. Standard error calculated from duplicate $(n=34)$, triplicate $(n=3)$, and quadruplicate $(n=6)$ analysis of individual fibers was $13 \%$.

Data Analysis Statistical analysis was performed using Matlab (Natick, MA, USA). Parametric statistical methods were chosen because groups of data in general were normally distributed based on the Lilliefors test of normality. Correlation coefficients between measured continuous parameters were determined using Pearson's product-moment correlations, and sample groups were compared using Student's $t$ test. Statistical results were deemed significant if $p<0.05$. Unless otherwise noted, summarized data reported in the text are average \pm standard deviation.

\section{Results}

Environmental Conditions Tide stage, daily calculated tide ranges, observed breaker heights, and times of surf zone and offshore sampling events are shown for both experiments in Fig. 3. Tidal range during July 2006 was approximately sinusoidal with a fortnightly period, with highest tidal range occurring around the day of the new moon. In March 2007, one or more long-period tidal oscillations slightly reduced the tide range during the new moon.

Breaker heights calculated from buoy data following Komar (1998) were compared with observations made in the surf zone, as described in the "Methods and Materials" section. A correction factor of 0.36 was used based on linear regression of observed and predicted breaker heights. This correction factor was applied to the entire predicted breaker dataset. Corrected predictions of breaker height are plotted with observed breaker heights in Fig. 3. Root mean square error between observed and predicted breaker heights was $19 \%$.

Breaker heights in the surf zone during the July 2006 experiment were smaller and more stable $(71 \pm 12 \mathrm{~cm})$ compared to the March 2007 experiment when breakers were significantly larger and more variable $(104 \pm 23 \mathrm{~cm} ; t=$ $-4.8, p<0.05$; Fig. 3). Field observations confirmed the arrival of multiple large swell events at the beach during the March 2007 experiment.

According to Stinson Beach County Water District records, 2.1 and $24.7 \mathrm{~cm}$ of rainfall had fallen in the 3 months prior to the July 2006 and March 2007 studies, highlighting the Mediterranean climate at the site. Rainfall during the actual experiments themselves was slight, with only 0.05 and $0.3 \mathrm{~cm}$ falling during the July 2006 and March 2007 studies, respectively.
Nutrients Nutrient concentrations for all sample groups are reported in Table 1. Nutrient measurements from July reported by de Sieyes et al. (2008) are included for comparison. Pit and seep samples were significantly enriched in phosphate, silicate, and dissolved inorganic nitrogen above both surf zone and offshore samples ( $p<0.05$ for both July 2006 (de Sieyes et al. 2008) and March 2007).

${ }^{223} \mathrm{Ra}$ and ${ }^{224} \mathrm{Ra}$ All samples were analyzed for the two short-lived radium isotopes ${ }^{223} \mathrm{Ra}$ and ${ }^{224} \mathrm{Ra}$ (Table 1). As with nutrient concentrations, activities of ${ }^{223} \mathrm{Ra}$ and ${ }^{224} \mathrm{Ra}$ activities were enriched in pit and seep samples compared to surf zone and offshore samples, suggesting groundwaterassociated discharge of radium to the nearshore. In March 2007, a single sample collected from Webb Creek, the only major creek in the area discharging directly to the ocean, contained ${ }^{223} \mathrm{Ra}$ and ${ }^{224} \mathrm{Ra}$ activities of 0.5 and $4.3 \mathrm{dpm}$ $(100 \mathrm{~L})^{-1}$, respectively.

When activities of ${ }^{223} \mathrm{Ra}$ are plotted as a function of ${ }^{224} \mathrm{Ra}$ for all samples, data generally fall along a line with a slope of 19, suggesting a common source for both isotopes (Fig. 4). A single sample from a hot spring with a ${ }^{224} \mathrm{Ra} /{ }^{223} \mathrm{Ra}$ isotopic ratio of approximately 56 deviates substantially from this common mixing line, suggesting it represents a distinct end member. However, none of the other samples falls along a mixing line between seawater and the hot spring end member, indicating that the hot spring has little or no influence on ${ }^{223} \mathrm{Ra}$ and ${ }^{224} \mathrm{Ra}$ activities in surface water and groundwater at our site.

To investigate homogeneity of $\mathrm{Ra}$ activities in the alongshore direction during each experiment, we tested whether ${ }^{223} \mathrm{Ra}$ and ${ }^{224} \mathrm{Ra}$ activities measured at the two cross-shore transects (Fig. 1) were significantly different using Student's $t$ test ( $t$ statistics not shown). For both the July 2006 and March 2007 studies, ${ }^{223} \mathrm{Ra}$ and ${ }^{224} \mathrm{Ra}$ activities collected from pits along the two transects were not significantly different $(0.34 \leq p \leq 0.90)$, suggesting groundwater activities are relatively homogeneous at this spatial scale. No significant differences were found between the samples collected at ankle depth along the two transects $(0.55<p<0.69)$ or at waist depth along the two transects $(0.36<p<0.99)$. The lack of significant differences between surf zone activities along the two transects indicates that radium activities are relatively homogeneous in the surf zone in the alongshore direction on the hundred meter scale.

We tested whether the surf zone was well mixed in the cross-shore direction with respect to ${ }^{223} \mathrm{Ra}$ and ${ }^{224} \mathrm{Ra}$ by comparing activities of ankle and waist depth samples for each experiment. In July $2007,{ }^{223} \mathrm{Ra}$ samples collected at ankle and waist depth were not significantly different $\left(t_{223}\right.$, ${ }_{\text {Jul06 }}=1.28, p=0.20$ ). In all other comparisons, activities at ankle depth were significantly higher than at waist depth $\left(t_{223}\right.$, Mar07 $=2.57, p=0.01 ; t_{224, \mathrm{Jul} 06}=2.24, p=0.028 ; t_{224, \mathrm{Mar} 07}=$ 
Table 1 Average concentrations \pm standard deviation of phosphate, silicate, dissolved inorganic nitrogen (DIN), ${ }^{223} \mathrm{Ra}$, and ${ }^{224} \mathrm{Ra}$ as a function of sample type for both experiments

\begin{tabular}{|c|c|c|c|c|c|c|}
\hline Experiment & Group & Phosphate $(\mu \mathrm{M})$ & Silicate $(\mu \mathrm{M})$ & $\operatorname{DIN}(\mu \mathrm{M})$ & ${ }^{223} \mathrm{Ra}\left(\mathrm{dpm} 100 \mathrm{~L}^{-1}\right)$ & ${ }^{224} \mathrm{Ra}\left(\mathrm{dpm} 100 \mathrm{~L}^{-1}\right)$ \\
\hline \multirow[t]{5}{*}{ July 2006} & Pits & $2.7 \pm 0.2$ & $140.6 \pm 17.8$ & $27.0 \pm 12.3$ & $7.8 \pm 2.7$ & $117.9 \pm 29.6$ \\
\hline & Seeps & $2.4 \pm 0.3$ & $102.4 \pm 18.4$ & $22.3 \pm 9.4$ & $4.0 \pm 1.4$ & $70.1 \pm 17.5$ \\
\hline & Surf zone & $1.7 \pm 0.2$ & $44.9 \pm 5.4$ & $19.3 \pm 3.2$ & $1.7 \pm 0.7$ & $30.0 \pm 10.3$ \\
\hline & Offshore & $1.6 \pm 0.3$ & $40.8 \pm 3.9$ & $17.9 \pm 3.5$ & $0.7 \pm 0.3$ & $12.2 \pm 6.3$ \\
\hline & Bolinas & $1.6 \pm 0.1$ & $45.9 \pm 3.5$ & $16.1 \pm 1.9$ & $2.2 \pm 0.4$ & $45.2 \pm 15.2$ \\
\hline \multirow[t]{5}{*}{ March 2007} & Pits & $2.6 \pm 0.3$ & $130.1 \pm 15.4$ & $30.4 \pm 6.5$ & $8.4 \pm 3.0$ & $106.7 \pm 35.2$ \\
\hline & Seeps & $2.1 \pm 0.1$ & $105.9 \pm 15.7$ & $29.7 \pm 4.4$ & $5.1 \pm 0.0$ & $88.8 \pm 1.8$ \\
\hline & Surf zone & $1.2 \pm 0.3$ & $26.0 \pm 5.5$ & $15.4 \pm 3.5$ & $1.5 \pm 0.6$ & $23.5 \pm 6.7$ \\
\hline & Offshore & $1.1 \pm 0.1$ & $28.8 \pm 9.6$ & $15.6 \pm 2.1$ & $0.6 \pm 0.2$ & $9.3 \pm 2.7$ \\
\hline & Bolinas & $1.4 \pm 0.1$ & $40.6 \pm 8.9$ & $9.3 \pm 2.4$ & $4.2 \pm 0.9$ & $67.2 \pm 9.4$ \\
\hline
\end{tabular}

Phosphate, silicate, and DIN for July 2006 are reported in de Sieyes et al. (2008)

$\left.3.59, p<10^{-3}\right)$. The cross-shore variation within the surf zone was on the order of $10-25 \%$ of the mean radium activity at ankle depth. This variability is small compared to the differences between the surf zone and other major sample groups including Bolinas Lagoon, offshore waters, pits, and seeps. For the purposes of further analysis, we group ankleand waist-deep surf zone samples for each isotope, referring to them collectively as the surf zone sample group.

If groundwater discharge at the shoreline is the major source of radium to the nearshore, then it follows that tracer activities should show a decreasing trend from groundwater to nearshore to offshore waters. Statistical testing was conducted to confirm this relationship; $t$ and $p$ values for the following tests are reported in Table 2. Pit samples were significantly enriched above seep samples during the July

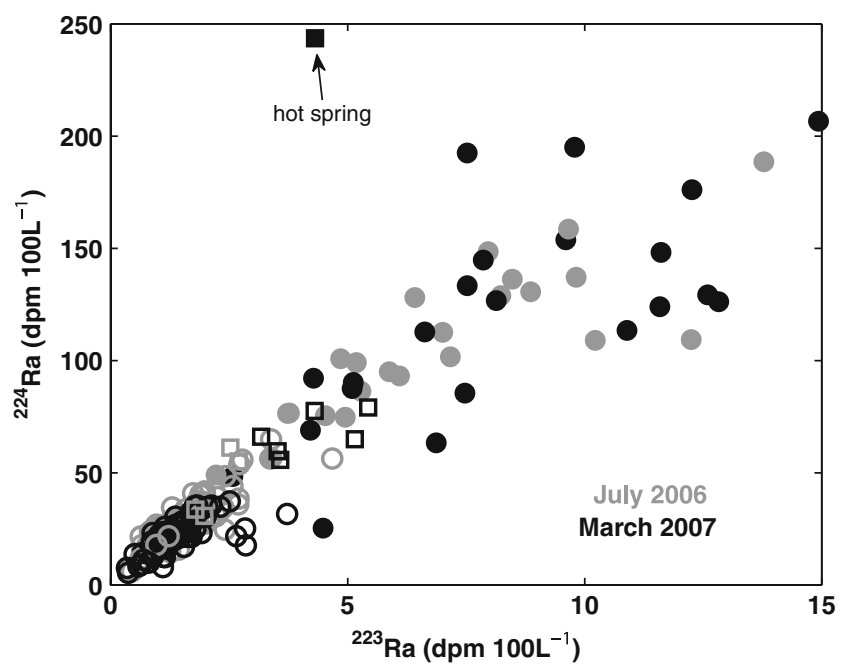

Fig. $4{ }^{224} \mathrm{Ra}$ activity as a function of ${ }^{223} \mathrm{Ra}$ activity for all samples collected as part of this study. Offshore and surf zone samples are open circles, groundwater samples including pits, seeps, and monitoring wells are filled circles, Bolinas Lagoon samples are open boxes, and the hot spring is a filled box
2006 experiment (Fig. 5) but not during the March 2007 experiment when only two seepage face samples were collected. For both isotopes during both experiments, surf zone activities were significantly lower than both pit samples and seepage face samples. Similarly, the surf zone was significantly enriched in both radium isotopes compared to offshore waters during both experiments.

Ebb flow from Bolinas Lagoon was enriched in ${ }^{223} \mathrm{Ra}$ and ${ }^{224} \mathrm{Ra}$ relative to offshore waters during both experiments (Table 2; Fig. 5), suggesting submarine groundwater discharge to the lagoon throughout the year. During the March 2007 experiment, the lagoon was also enriched in both isotopes relative to surf zone waters whereas during the July 2006 experiment, the lagoon was significantly enriched over surf zone activities in ${ }^{224} \mathrm{Ra}$ but differences in ${ }^{223} \mathrm{Ra}$ activities were not significant. Mean ${ }^{223} \mathrm{Ra}$ and ${ }^{224} \mathrm{Ra}$ activities in Bolinas Lagoon were higher than mean surf zone activities by $170 \%$ and $190 \%$ in March 2007 and by $40 \%$ and $50 \%$ in July 2006. In comparison, Bolinas Lagoon waters contained significantly less of each isotope than groundwater samples from pits during the July 2006 experiment. The same relationship was true for ${ }^{224} \mathrm{Ra}$ in March 2007, but differences in ${ }^{223} \mathrm{Ra}$ were not statistically significant.

Radium activities in sample groups were compared between the two experiments to test for seasonal differences. ${ }^{223} \mathrm{Ra}$ and ${ }^{224} \mathrm{Ra}$ activities in pit and seep samples were not different between summer and winter, indicating a seasonally stable groundwater end member with respect to ${ }^{223} \mathrm{Ra}$ and ${ }^{224} \mathrm{Ra}$ activities (Table 2; Fig. 5). Activities of the longer-lived isotope ${ }^{223} \mathrm{Ra}$ in the surf zone were not significantly different between the two experiments, but ${ }^{224} \mathrm{Ra}$ activities in the surf zone were significantly lower during the March 2007 experiment relative to July 2006 by $22 \%$. Differences between offshore ${ }^{223} \mathrm{Ra}$ and ${ }^{224} \mathrm{Ra}$ activities during the two studies were insignificant. Bolinas Lagoon was significantly enriched in ${ }^{223} \mathrm{Ra}$ and ${ }^{224} \mathrm{Ra}$ by 
Table $2 t$ and $p$ values for ${ }^{223} \mathrm{Ra}$ (upper right half) and ${ }^{224} \mathrm{Ra}$ (lower left half) comparisons across groups and experiments

\begin{tabular}{|c|c|c|c|c|c|c|c|c|c|c|c|}
\hline & & \multicolumn{5}{|l|}{ July 2006} & \multicolumn{5}{|c|}{ March 2007} \\
\hline & & Pits & Seeps & $\begin{array}{l}\text { Surf } \\
\text { Zone }\end{array}$ & Offshore & Bolinas & Pits & Seeps & Surf Zone & Offshore & Bolinas \\
\hline \multirow[t]{5}{*}{ July 2006} & Pits & & $\begin{array}{l}t=2.97 \\
p=0.007\end{array}$ & $\begin{array}{l}t=-17.7 \\
p<10^{-30}\end{array}$ & $\mathrm{n} / \mathrm{a}$ & $\begin{array}{l}t=-4.0 \\
p<10^{-3}\end{array}$ & $\begin{array}{l}t=-1.23 \\
p=0.22\end{array}$ & $\mathrm{n} / \mathrm{a}$ & $\mathrm{n} / \mathrm{a}$ & $\mathrm{n} / \mathrm{a}$ & $\mathrm{n} / \mathrm{a}$ \\
\hline & Seeps & $\begin{array}{l}t=3.42 \\
p=0.003\end{array}$ & & $\begin{array}{l}t=-6.8 \\
p<10^{-8}\end{array}$ & $\mathrm{n} / \mathrm{a}$ & $\mathrm{n} / \mathrm{a}$ & $\mathrm{n} / \mathrm{a}$ & $\mathrm{n} / \mathrm{a}$ & $\mathrm{n} / \mathrm{a}$ & $\mathrm{n} / \mathrm{a}$ & $\mathrm{n} / \mathrm{a}$ \\
\hline & Surf Zone & $\begin{array}{l}t=-21.3 \\
p<10^{-36}\end{array}$ & $\begin{array}{l}t=-8.1 \\
p<10^{-11}\end{array}$ & & $\begin{array}{l}t=3.38 \\
p=0.011\end{array}$ & $\begin{array}{l}t=1.71 \\
p=0.092\end{array}$ & $\mathrm{n} / \mathrm{a}$ & $\mathrm{n} / \mathrm{a}$ & $\begin{array}{l}t=1.13 \\
p=0.26\end{array}$ & $\mathrm{n} / \mathrm{a}$ & $\mathrm{n} / \mathrm{a}$ \\
\hline & Offshore & $\mathrm{n} / \mathrm{a}$ & $\mathrm{n} / \mathrm{a}$ & $\begin{array}{l}t=4.16 \\
p<10^{-4}\end{array}$ & & $\begin{array}{l}t=6.47 \\
p<10^{-3}\end{array}$ & $\mathrm{n} / \mathrm{a}$ & $\mathrm{n} / \mathrm{a}$ & $\mathrm{n} / \mathrm{a}$ & $\begin{array}{l}t=0.99 \\
p=0.34\end{array}$ & $\mathrm{n} / \mathrm{a}$ \\
\hline & Bolinas & $\begin{array}{l}t=-2.5 \\
p<10^{-3}\end{array}$ & $\mathrm{n} / \mathrm{a}$ & $\begin{array}{l}t=2.82 \\
p=0.006\end{array}$ & $\begin{array}{l}t=4.83 \\
p=0.0013\end{array}$ & & $\mathrm{n} / \mathrm{a}$ & $\mathrm{n} / \mathrm{a}$ & $\mathrm{n} / \mathrm{a}$ & $\mathrm{n} / \mathrm{a}$ & $\begin{array}{l}t=-3.85 \\
p=0.0049\end{array}$ \\
\hline \multirow[t]{5}{*}{ March 2007} & Pits & $\begin{array}{l}t=0.27 \\
p=0.78\end{array}$ & $\mathrm{n} / \mathrm{a}$ & $\mathrm{n} / \mathrm{a}$ & $\mathrm{n} / \mathrm{a}$ & $\mathrm{n} / \mathrm{a}$ & & $\begin{array}{l}t=0.71 \\
p=0.49\end{array}$ & $\begin{array}{l}t=-6.1 \\
p<10^{-7}\end{array}$ & $\mathrm{n} / \mathrm{a}$ & $\begin{array}{l}t=-1.4 \\
p=0.17\end{array}$ \\
\hline & Seeps & $\mathrm{n} / \mathrm{a}$ & $\mathrm{n} / \mathrm{a}$ & $\mathrm{n} / \mathrm{a}$ & $\mathrm{n} / \mathrm{a}$ & $\mathrm{n} / \mathrm{a}$ & $\begin{array}{l}t=0.78 \\
p=0.45\end{array}$ & & $\begin{array}{l}t=-22.2 \\
p=0.029\end{array}$ & $\mathrm{n} / \mathrm{a}$ & $\mathrm{n} / \mathrm{a}$ \\
\hline & Surf Zone & $\mathrm{n} / \mathrm{a}$ & $\mathrm{n} / \mathrm{a}$ & $\begin{array}{l}t=1.13 \\
p=0.26\end{array}$ & $\mathrm{n} / \mathrm{a}$ & $\mathrm{n} / \mathrm{a}$ & $\begin{array}{l}t=-14.8 \\
p<10^{-22}\end{array}$ & $\begin{array}{l}t=-19.5 \\
p=0.033\end{array}$ & & $\begin{array}{l}t=4.41 \\
p<10^{-4}\end{array}$ & $\begin{array}{l}t=10.13 \\
p<10^{-13}\end{array}$ \\
\hline & Offshore & $\mathrm{n} / \mathrm{a}$ & $\mathrm{n} / \mathrm{a}$ & $\mathrm{n} / \mathrm{a}$ & $\begin{array}{l}t=1.09 \\
p=0.30\end{array}$ & $\mathrm{n} / \mathrm{a}$ & $\mathrm{n} / \mathrm{a}$ & $\mathrm{n} / \mathrm{a}$ & $\begin{array}{l}t=5.50 \\
p<10^{-6}\end{array}$ & & $\begin{array}{l}t=10.19 \\
p<10^{-8}\end{array}$ \\
\hline & Bolinas & $\mathrm{n} / \mathrm{a}$ & $\mathrm{n} / \mathrm{a}$ & $\mathrm{n} / \mathrm{a}$ & $\mathrm{n} / \mathrm{a}$ & $\begin{array}{l}t=-2.85 \\
p=0.021\end{array}$ & $\begin{array}{l}t=-4.0 \\
p=0.021\end{array}$ & $\mathrm{n} / \mathrm{a}$ & $\begin{array}{l}t=14.61 \\
p<10^{-20}\end{array}$ & $\begin{array}{l}t=15.7 \\
p<10^{-8}\end{array}$ & \\
\hline
\end{tabular}

$86 \%$ and $49 \%$, respectively, during the March 2007 experiment compared to the July 2006 experiment.

To test the role of tide level in explaining radium variability in the surf zone, the four samples collected in the surf zone during each low-tide sampling event were grouped and compared by paired $t$ test to the corresponding four samples collected during the previous high tide. In July $2006,{ }^{223} \mathrm{Ra}$ and ${ }^{224} \mathrm{Ra}$ activities in the surf zone were significantly higher at low tides than at preceding high tides $\left(t_{223, J u l 06}=-4.89, p<\right.$ $\left.10^{-4} ; t_{224, \mathrm{Ju} 106}=-6.65, p<10^{-6}\right)$, with mean ${ }^{223} \mathrm{Ra}$ and ${ }^{224} \mathrm{Ra}$ activities at low tides $87 \%$ and $95 \%$ higher than at preceding high tides, respectively. In March 2007, mean ${ }^{223} \mathrm{Ra}$ and ${ }^{224} \mathrm{Ra}$ activities were $80 \%$ and $60 \%$ higher at low tides than at preceding high tides, respectively, but the difference was only statistically significant for ${ }^{223} \mathrm{Ra}\left(t_{223, \mathrm{Mar} 07}=-3.36, p=\right.$ $\left.0.0024 ; t_{224, \mathrm{Mar} 07}=-2.00, p=0.055\right)$.

Radium activity in the surf zone was compared to daily tidal range in order to examine the role of fortnightly neap-spring tidal variability on surf zone radium activity. Neither ${ }^{223}$ Ra nor ${ }^{224} \mathrm{Ra}$ activity in the surf zone was significantly correlated to tidal range when grouped by experiment $\left(r_{223, \mathrm{Ju} 106}=0.22, p=\right.$ $0.055 ; r_{223, \mathrm{Mar} 07}=0.12, p=0.37 ; r_{224, \mathrm{Ju} 106}=0.16, p=0.18 ; r_{224}$, Mar07 $=0.24, p=0.070$ ). When samples from both experiments were grouped together, a significant positive correlation emerged between tidal range and both ${ }^{223} \mathrm{Ra}$ and ${ }^{224} \mathrm{Ra}$ $\left(r_{223}=0.20, p=0.019 ; r_{224}=0.26, p=0.0022\right)$.

A similar comparison was made for each experiment to investigate the correlation between average daily breaker height on surf zone radium activity. During the July 2006 experiment, ${ }^{223} \mathrm{Ra}$ and ${ }^{224} \mathrm{Ra}$ activities in the surf zone were significantly negatively correlated with breaker height $\left(r_{223}=\right.$ $\left.-0.44, p=0.0001 ; r_{224}=-0.43, p=0.0001\right)$. Interestingly, during the March 2007 experiment when breaking waves in the surf zone were noticeably larger, the short-lived isotope ${ }^{224} \mathrm{Ra}$ in the surf zone was significantly positively correlated with breaker height $\left(r_{224}=0.38, p=0.0043\right)$. No significant relationship existed between daily mean breaker height and ${ }^{223} \mathrm{Ra}$ in the surf zone during the March 2007 experiment $\left(r_{223}=0.19, p=0.14\right)$.

${ }^{226} \mathrm{Ra}{ }^{226} \mathrm{Ra}$ activities for sample groups are compared in Fig. 6. During the July 2006 experiment, pit samples were significantly enriched in ${ }^{226} \mathrm{Ra}$ above surf zone activities, consistent with a groundwater ${ }^{226} \mathrm{Ra}$ source $(t=3.47$; $p=$ $0.0014)$. However, offshore samples were also significantly enriched in ${ }^{226} \mathrm{Ra}$ above surf zone activities $\left(t_{\mathrm{Jul06}}=-3.97\right.$; $p<10^{-3}$ ), inconsistent with a coastal groundwater source (Fig. 6). By comparison, during the March 2007 experiment, ${ }^{226} \mathrm{Ra}$ activities in pit and surf zone samples were not significantly different $(t=-0.85 ; p=0.40)$, but the surf zone was enriched relative to offshore waters $\left(t_{\mathrm{Mar} 07}=2.68 ; p=\right.$ 0.012). ${ }^{226} \mathrm{Ra}$ activities in Bolinas Lagoon were not significantly different than those in the surf zone during either experiment $\left(t_{\mathrm{Ju} 106}=-1.76, p=0.095 ; t_{\mathrm{Mar} 07}=-0.47\right.$, $p=0.64)$. The lagoon was enriched in ${ }^{226} \mathrm{Ra}$ relative to offshore waters in March $2007(t=-3.23 ; p=0.0042)$ but not in July $2006\left(t_{\mathrm{Mar} 07}=1.19, p=0.24\right)$. A March 2007 water sample from the hot spring located on the shoreline approximately $1.8 \mathrm{~km}$ from the research site contained very high ${ }^{226} \mathrm{Ra}$ activities of $148 \mathrm{dpm}(100 \mathrm{~L})^{-1}$, 

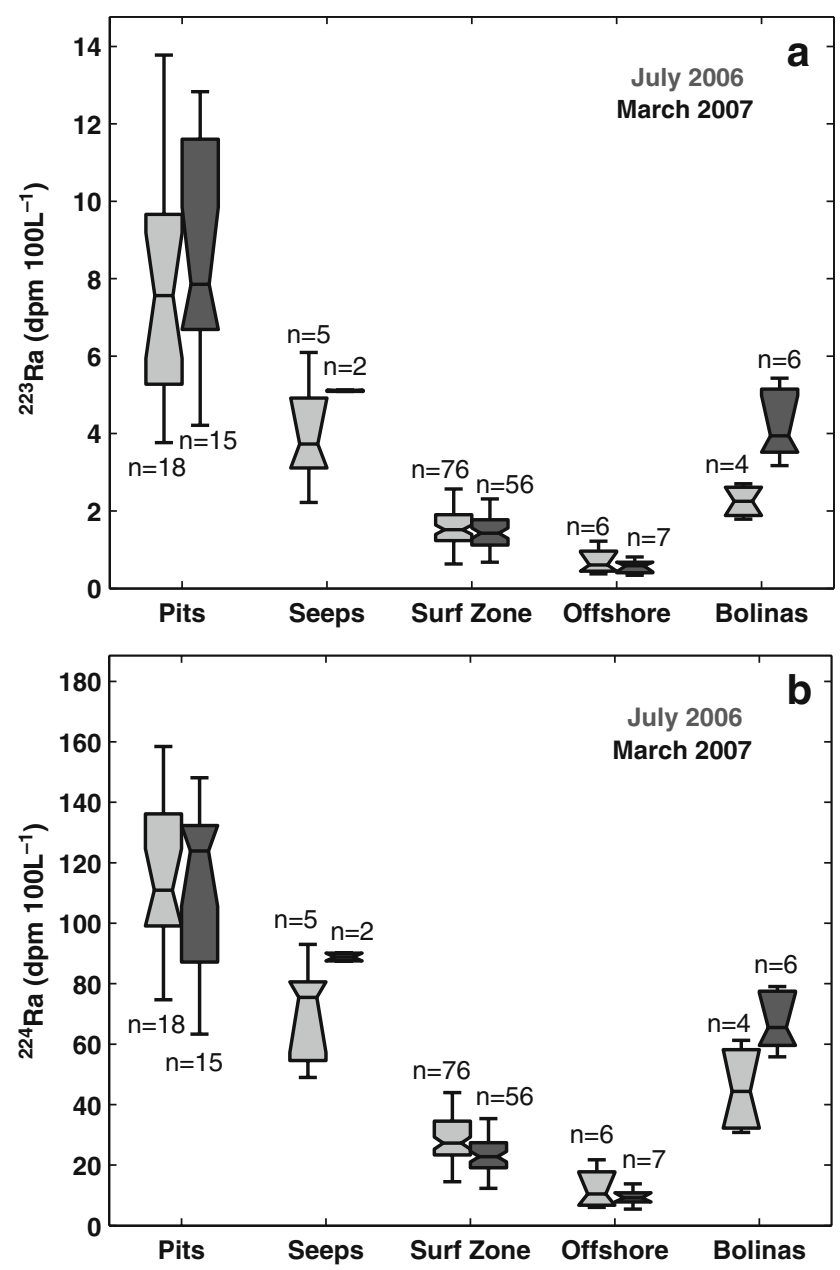

Fig. $5{ }^{223} \mathrm{Ra}$ (a) and ${ }^{224} \mathrm{Ra}$ (b) activities by sample group during the July 2006 and March 2007 experiments

approximately an order of magnitude above that of beach groundwater.

Creek Survey A survey of local creeks was conducted during the March 2007 experiment in order to provide an estimate of total creek-associated nutrient flux during the wet season for comparison with SGD-associated nutrient flux estimates (Table 3). Total flux from all creeks discharging to Bolinas Lagoon and directly to the ocean near Stinson Beach at the time of the March experiment was estimated at $10 \pm$ $1 \mathrm{mmol} \mathrm{min}-1$ phosphate, $3 \pm 1 \mathrm{~mol} \mathrm{~min}^{-1}$ silicate, and $200 \pm$ $50 \mathrm{mmol} \mathrm{min}^{-1}$ dissolved inorganic nitrogen.

\section{Discussion}

Tide Level During both the summer and winter studies, ${ }^{223} \mathrm{Ra}$ activities in the surf zone were significantly higher at low tides than at preceding high tides. For ${ }^{224} \mathrm{Ra}$, the same trend

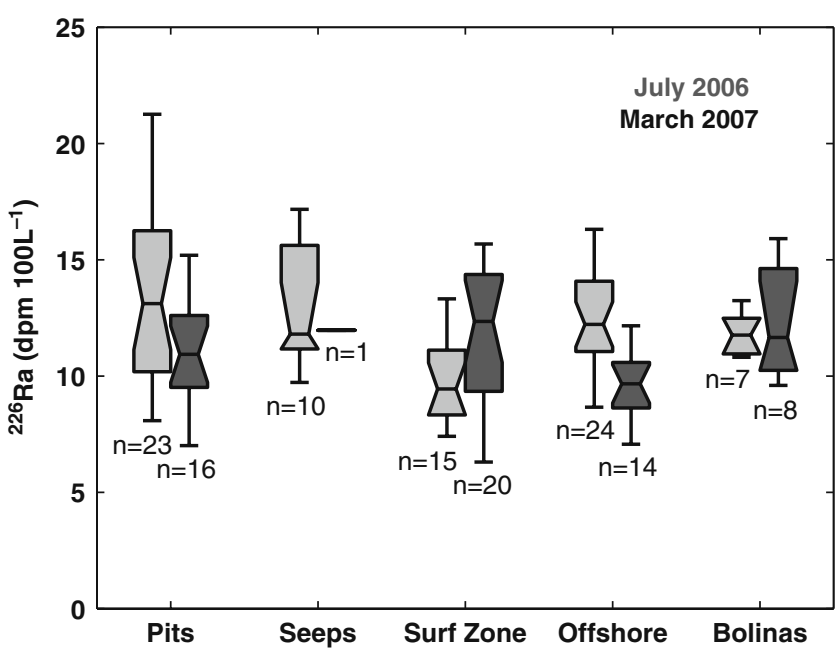

Fig. $6{ }^{226} \mathrm{Ra}$ activities by sample group during the July 2006 and March 2007 experiments. Included in $n$ are duplicate and triplicate analyses for individual samples. The hot spring sample collected in March $2007\left(148 \mathrm{dpm}(100 \mathrm{~L})^{-1}\right)$ is not shown

was observed although results were statistically significant only for the July 2006 experiment. The increased ${ }^{223} \mathrm{Ra}$ and ${ }^{224} \mathrm{Ra}$ activities observed during low tides suggest discharge of tidally pumped, radium-enriched groundwater out of the beach aquifer during ebb tides. This interpretation is consistent with results from other studies documenting tidal pumping (Boehm et al. 2004). An alternative explanation for the increased radium activity between low and high tide is that the surf zone becomes enriched in radium at low tide by the outflow of Bolinas Lagoon. However, it should be noted that sediment transport studies suggest that ebb outflow from Bolinas Lagoon typically flows toward the northwest, away from our sampling sites (Philip Williams \& Associates 2005). This suggests that Bolinas ebb flow is not directed to the south, toward our study site.

Fortnightly Tides The magnitude of SGD forced by tidal pumping is directly affected by the magnitude of tidal range, or the difference in elevation between high and low tide (Ataie-Ashtiani et al. 2001). Assuming constant rates of cross-shore mixing, one might expect that SGDassociated radium would increase in the surf zone during periods of highest tidal range. Indeed, tidal range during our studies did explain $4 \%$ and $7 \%$ of the variation in ${ }^{223} \mathrm{Ra}$ and ${ }^{224} \mathrm{Ra}$ in the surf zone, respectively. This significant positive correlation is consistent with previous studies concluding that tidal range does influence the magnitude of tidal pumping of groundwater from the beach aquifer, with the greatest discharge occurring at or around spring tide (Li et al. 1999; Rapaglia 2005; de Sieyes et al. 2008).

An alternative interpretation of the radium enrichment of the surf zone at spring tide is that Bolinas Lagoon is disproportionately enriching the surf zone with radium at 
Table 3 Results of the creek survey

\begin{tabular}{|c|c|c|c|c|c|c|c|c|c|}
\hline Watershed & Latitude & Longitude & $\begin{array}{l}\text { Phosphate } \\
(\mu \mathrm{M})\end{array}$ & $\begin{array}{l}\text { Silicate } \\
(\mu \mathrm{M})\end{array}$ & $\begin{array}{l}\text { DIN } \\
(\mu \mathrm{M})\end{array}$ & $\begin{array}{l}\text { Flow Rate } \\
(\mathrm{L} \mathrm{min}-1)\end{array}$ & 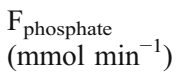 & 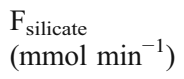 & 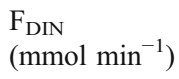 \\
\hline Audobon Creek & 37.930 & -122.681 & 1.8 & 290 & 4.9 & 900 & 2 & 300 & 4 \\
\hline Black Rock Creek & 37.898 & -122.635 & 0.9 & 330 & 26.8 & 300 & 0.3 & 100 & 8 \\
\hline Bolinas Creek & 37.920 & -122.693 & 1.7 & 376 & 22.0 & 4,000 & 7 & 2,000 & 100 \\
\hline Culvert \#1 & 37.932 & -122.698 & 0.7 & 365 & 16.9 & 70 & 0.1 & 30 & 1 \\
\hline Fitzhenry Creek & 37.900 & -122.637 & 0.9 & 338 & 34.7 & 700 & 0.7 & 200 & 30 \\
\hline McKinnan Gulch & 37.913 & -122.660 & 1.1 & 264 & 14.9 & 2,000 & 2 & 500 & 30 \\
\hline Pike County Gulch & 37.932 & -122.688 & 0.3 & 262 & 2.2 & 100 & 0.1 & 40 & 0.3 \\
\hline Stinson Gulch \#1 & 37.907 & -122.651 & 0.8 & 207 & 8.2 & 400 & 0.3 & 90 & 4 \\
\hline Stinson Gulch \#2 & 37.907 & -122.651 & 0.7 & 265 & 6.6 & 300 & 0.2 & 80 & 2 \\
\hline Stinson Gulch \#3 & 37.907 & -122.651 & 0.4 & 291 & 3.2 & 900 & 0.3 & 300 & 3 \\
\hline Volunteer Canyon & 37.925 & -122.675 & 0.6 & 284 & 1.1 & 100 & 0.1 & 40 & 0.2 \\
\hline Webb Creek & 37.887 & -122.626 & 0.5 & 299 & 20.9 & 700 & 0.3 & 200 & 10 \\
\hline
\end{tabular}

Concentrations are reported in units of micromoles per liter, flow rates are in liters per minute, and calculated nutrient fluxes have units of millimoles per minute. Standard deviations of nutrient fluxes are $25 \%$, the result of propagated standard deviations of nutrient concentration (5\%), and flow rate (25\%). Culvert \#1 is an unnamed storm drain and Stinson Gulch \#1, \#2, and \#3 are the three branches draining Stinson Gulch

that point in the fortnightly tidal cycle. While increases in tidally pumped groundwater during periods of increased tidal range are consistent with the numerical simulations of others (Ataie-Ashtiani et al. 2001), we cannot discount this possibility. However, as mentioned before, the limited available data on ebb flow from the lagoon mouth is not consistent with this interpretation (Philip Williams \& Associates 2005). More specific work following radium activity in the ebb plumes from the lagoon is needed to quantitatively evaluate the contribution of this source.

Waves The role of wave setup and wave run-up in driving SGD has been explored by other researchers numerically and using field measurements. Increases in breaker height have been shown not only to increase wave pumping of SGD (Longuet-Higgins 1983) but also to increase crossshore mixing in the nearshore (Pearson et al. 2002). Significant negative correlations were observed between breaker height and activities of ${ }^{223} \mathrm{Ra}$ or ${ }^{224} \mathrm{Ra}$ in the surf zone during the July 2006 experiment, with breaker height explaining $44 \%$ and $43 \%$ of activity for the two isotopes, respectively. The negative correlations in the summer experiment suggest either reduced discharge during periods of higher breaking waves, increased cross-shore mixing with radium-poor offshore waters, or both. Given the expected role of waves in driving groundwater flow (larger waves, larger setup, and thus larger wave pumped SGD), our results suggest that, during summer when breaker height is comparatively small, the net effect of increased breaker height is increased mixing with radium-poor offshore waters rather than decreased discharge. During the March 2007 experiment when breaker height was larger and more variable compared to the summer, surf zone activities of the short-lived isotope ${ }^{224} \mathrm{Ra}$ were significantly positively correlated with breaker height. In March, variations in breaker height explained $38 \%$ of the radium variability. This relationship is consistent with increased wave-driven SGD during large winter swell events. To the best of our knowledge, no other studies have observed a significant relationship between breaker height and groundwater tracer concentrations in open waters receiving SGD.

SGD Estimates and Seasonal Comparison Numerous lines of evidence support the use of the two short-lived radium isotopes ${ }^{223} \mathrm{Ra}$ and ${ }^{224} \mathrm{Ra}$ as tracers of beach groundwater flow to the ocean. The decrease in activity from groundwater to surf zone and Bolinas Lagoon waters to offshore waters is consistent with the conceptual model of a groundwater tracer source discharging in this setting. Conversely, no consistent, statistically significant patterns emerged that suggested beach groundwater as the primary source of the long-lived isotope ${ }^{226} \mathrm{Ra}$ to the nearshore. This lack of a clear pattern may be a combination of the multiple sources of the long-lived isotope ${ }^{226} \mathrm{Ra}$ in this environment, including beach groundwater, ${ }^{226} \mathrm{Ra}$ from hot springs, the outflow of Bolinas Lagoon, and possibly the outflow of San Francisco Bay, which was not investigated in this study. Point Reyes is a major upwelling center, and upwelled waters may also be another important source of ${ }^{226} \mathrm{Ra}$ to the coastal ocean in this area. ${ }^{226} \mathrm{Ra}$ activities monitored during the experiment were inconsistent with the assumptions required of methods using the offshore decay of groundwater-derived ${ }^{226} \mathrm{Ra}$ to calculate groundwater discharge (Moore 2000b, 2003). For this reason, we chose 
to estimate SGD using a mass balance of short-lived radium isotopes in the surf zone (Boehm et al. 2004; Paytan et al. 2006).

To estimate total groundwater discharge using the shortlived isotopes, we rely upon a surf zone "box" model which treats a single surf zone rip cell as a prism-shaped continuous flow reactor with constant volume and residence time (Fig. 2). This box model approach was previously utilized at Stinson Beach to estimate fresh groundwater discharge using salinity as a conservative tracer (de Sieyes et al. 2008) as well as at other locations (Shellenbarger et al. 2006). Observations of rip cell characteristics were logged and beach topography surveyed during each experiment (Fig. 2), and prism cell volume $V_{\text {prism }}$ was calculated from these characteristics. The average estimated surf zone width $w$, the distance from shoreline to just beyond breakers, was estimated at $20 \mathrm{~m}$ in July 2006 and $50 \mathrm{~m}$ in March 2007, and the breaker depth was calculated as the product of surf zone width $w$ and beach slope $s_{\mathrm{b}}$. The following equation was then used to estimate total groundwater discharge volume per unit length of shoreline $D$ using a Monte Carlo approach:

$D=\left(\frac{A_{\text {prism }}-A_{\text {offshore }}}{A_{\text {groundwater }}}\right) \frac{V_{\text {prism }}}{L \tau}$

where $\tau$ is the cross-shore residence time of water in the rip cell. During each of 100,000 iterations, the model calculated $D$ from random, normally distributed radium activities for the surf zone prism $A_{\text {prism, }}$ groundwater end member $A_{\text {groundwater, }}$ and offshore end member $A_{\text {offshore, based on }}$ mean and standard deviations measured for each group (Table 1). Each iteration incorporates random, evenly distributed values of surf zone residence time between 1 and $4 \mathrm{~h}$, the range of surf zone residence times used previously for estimating SGD at this site (de Sieyes et al. 2008). Uncertainties on $V_{\text {prism }}$ were not considered because they were not quantified as part of this study. It should be noted that Eq. 1 assumes that $D$ is small compared to the input of offshore waters into the surf zone via breaking waves and thus does not affect the water balance.

Given that the ${ }^{223} \mathrm{Ra}$ and ${ }^{224} \mathrm{Ra}$ activities were lower in Webb Creek than in offshore waters, they very likely do not contribute significant short-lived radium isotopes to the nearshore. For this reason, inputs from the creek are ignored in the mass balance. The mass balance assumes that all radium in the surf zone is derived from beach groundwater and not from other sources including Bolinas Lagoon, upwelled seawater, or San Francisco Bay.

Results of the surf zone mass balance are reported in Fig. 7. Shown are first, second, and third quartile estimates of SGD. Median (second quartile) estimates of $D$ based on ${ }^{223} \mathrm{Ra}$ and ${ }^{224} \mathrm{Ra}$ activities were 6 and $8 \mathrm{~L} \mathrm{~min}^{-1} \mathrm{~m}^{-1}$ in July 2006 and 38 and $43 \mathrm{~L} \mathrm{~min}^{-1} \mathrm{~m}^{-1}$ in March 2007, respectively.
SGD estimates were previously reported for this site using salinity as a tracer and models of saline groundwater discharge and found to be between 17 and $23 \mathrm{~L} \mathrm{~min}^{-1} \mathrm{~m}^{-1}$ during the dry season (de Sieyes et al. 2008). Those estimates are a factor of two to three higher than the median radium-based discharge rates reported here for the dry season. Discrepancies in SGD estimates obtained by independent methods is not unusual (Burnett et al. 2006).

A comparison of our radium-derived SGD estimates with those from locations with similar climates (Southern California and Israel) indicates our estimates are within the range of those previous reported. Boehm et al. (2006) estimated dry season discharge rates between 4.2 and $8.9 \mathrm{~L}$ $\min ^{-1} \mathrm{~m}^{-1}$ at Huntington Beach, CA, using a radium-based eddy diffusivity approach. Shellenbarger et al. (2006) reported annual average discharge rates of 1.0 to $4.5 \mathrm{~L}$ $\min ^{-1} \mathrm{~m}^{-1}$ in the Gulf of Aqaba, Israel, based on a coastal box model approach using radium as a groundwater tracer. These ranges match well with the median discharge estimates of 6 and $8 \mathrm{~L} \mathrm{~min}^{-1} \mathrm{~m}^{-1}$ we report for Stinson Beach for dry weather.

SGD estimates were significantly greater in March 2007 than in July 2006 based on both ${ }^{223} \mathrm{Ra}\left(t=-40.5, p<10^{-10}\right)$ and ${ }^{224} \mathrm{Ra}\left(t=-38.7, p<10^{-10}\right)$. This difference is driven mathematically by seasonal differences in radium activities and surf zone volume ( $\left.V_{\text {prism }}\right)$, as $V_{\text {prism }}$ is larger in winter than in summer due to larger waves breaking farther offshore in winter months. The large degree to which our median SGD estimates vary from summer and winter may result from the strongly seasonal precipitation-evapotranspiration cycle experienced in the Mediterranean climate of coastal Central California.

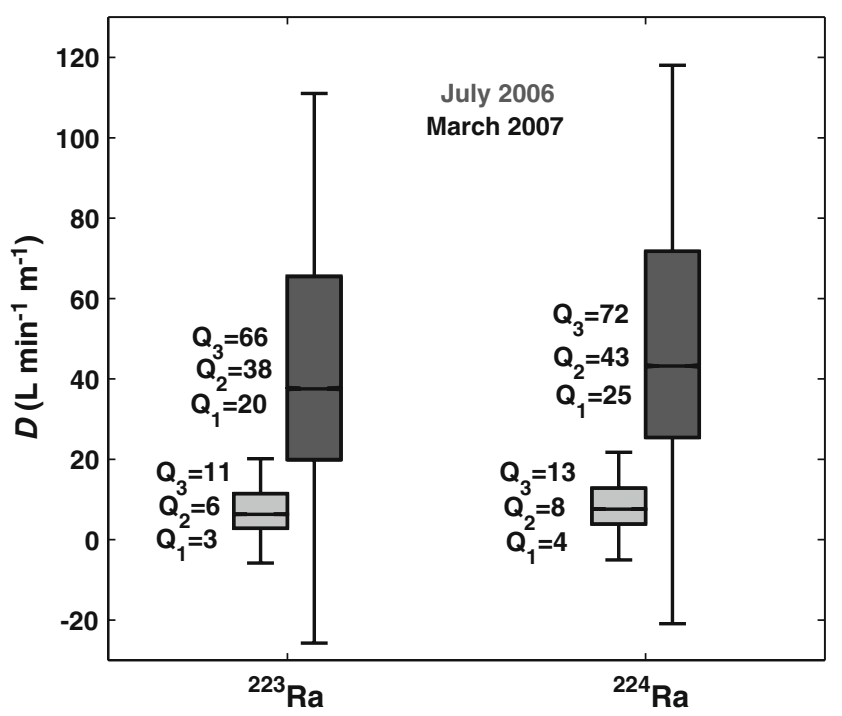

Fig. 7 Discharge estimates as calculated by Eq. 1 using a Monte Carlo approach. $Q 1, Q 2$, and $Q 3$ are the first, second, and third quartiles of discharge estimates, respectively 
Using Monte Carlo simulations allowed us to incorporate quantifiable uncertainties of input terms into our SGD estimates. Specifically, the radium activities incorporated in each model run were chosen based on standard deviations about mean radium activities for each sample group. The model also used a wide range of surf zone residence times, 1 to $4 \mathrm{~h}$, reflecting the uncertainty of that model input for the surf zone at the field site. Uncertainty was not quantifiable for the rip cell volume term $\left(V_{\text {prism }}\right)$, which was assumed constant in all simulations for a given experiment. Future work should examine uncertainty in this parameter.

Bolinas Lagoon was significantly enriched in both ${ }^{223} \mathrm{Ra}$ and ${ }^{224} \mathrm{Ra}$ during the March 2007 experiment compared to the July 2006. Because flow in this lagoon is dominated by tidal exchange (Philip Williams \& Associates 2005; Ritter 1973), we can assume that residence time therein likely remains approximately stable on the seasonal timescale. It follows that higher ${ }^{223} \mathrm{Ra}$ and ${ }^{224} \mathrm{Ra}$ activities in the lagoon in March are evidence of increased groundwater flux during the winter experiment, consistent with the seasonal variation in SGD reported above for the Stinson Beach shoreline. An estimate of either residence time or tidal exchange ratio could be used in conjunction with the radium activities presented here to estimate SGD to Bolinas Lagoon. Unfortunately, to the best of our knowledge, no published values exist for these parameters, and such a calculation is not possible at this time. The role played by SGD in the Bolinas Lagoon ecosystem, which has itself been recognized as an internationally significant ecological resource, should be a focus of future research.

Our previous work at the site has shown that groundwater at Stinson Beach is a major source of nutrients to the coastal ocean, with nutrient pollution in fresh groundwater due at least in part to the high density of septic systems in the community. A comparison between groundwaterassociated nutrient flux and that from creeks discharging locally during the March 2007 experiment further supports this conclusion. Total creek-associated nutrient flux ( \pm standard deviation) in March 2007 was estimated at $10 \pm$ $3 \mathrm{mmol} \mathrm{min}-1$ phosphate, $4 \pm 1 \mathrm{~mol} \mathrm{~min}{ }^{-1}$ silicate, and $200 \pm 50 \mathrm{mmol} \mathrm{min}^{-1}$ dissolved inorganic nitrogen. Assuming SGD-associated flux in March 2007 is the product of the median ${ }^{223}$ Ra-based SGD estimate, $38 \mathrm{~L} \mathrm{~min}^{-1} \mathrm{~m}^{-1}$, and mean pit nutrient concentrations of $2.6,130$, and $30.4 \mu \mathrm{M}$ phosphate, silicate, and DIN, respectively, total SGDassociated flux at the study site in March 2007 was $99 \mu \mathrm{mol}$ phosphate $\min ^{-1} \mathrm{~m}^{-1}, 4,940 \mu \mathrm{mol}$ silicate $\min ^{-1} \mathrm{~m}^{-1}$, and $1,160 \mu \mathrm{mol}$ DIN $\mathrm{min}^{-1} \mathrm{~m}^{-1}$. In other words, SGD from the short 200-m stretch of Stinson Beach where our experiments were conducted was responsible for a nutrient flux approximately equal to the total creek-associated flux of phosphate and dissolved inorganic nitrogen discharged within $6 \mathrm{~km}$ of the study site in March 2007. Surface water runoff in late summer along this area of coast was negligible, so a similar calculation for the July 2006 experiment was not made, but we can conclude that discharge of nutrientenriched groundwater discharge at Stinson Beach likely plays a particularly significant role in the local marine nutrient budget during the summer months. This highlights the importance of groundwater protection at Stinson Beach and similar coastal settings where discharge of groundwater to the coastal ocean occurs.

\section{Conclusions}

Submarine groundwater discharge was documented at Stinson Beach during two experiments. With the exception of ${ }^{224} \mathrm{Ra}$ during the March 2007 experiment, short-lived radium isotope activities in the surf zone were significantly higher at low tide relative to high tide, indicating the importance of tidal pumping along this coastline. Tidal range correlated significantly with ${ }^{223} \mathrm{Ra}$ and ${ }^{224} \mathrm{Ra}$ activity in the surf zone suggesting that the magnitude of discharge is controlled to some degree by the tidal range, with maximal discharge occurring during spring tide. Increases in wave action at the beach had a significant but opposite effect on radium activities in the surf zone during the summer and winter studies, highlighting the roles of waves in driving both SGD and cross-shore mixing. The arrival of large swell events at the beach in winter appeared to increase radium-enriched SGD to the surf zone.

This study did not investigate the potential effects of large-scale changes in flow and mixing from tides, wind, waves, upwelling, and other physical processes which may be influencing radium activities in the nearshore. Future studies investigating these processes would be useful in fully understanding the sources, fate, and transport of radium in coastal waters.

${ }^{226} \mathrm{Ra}$ was enriched in offshore waters relative to surf zone waters at the site, indicating shoreline groundwater discharge was not the sole source of ${ }^{226} \mathrm{Ra}$ to the nearshore. Bolinas Lagoon, San Francisco Bay, upwelling, and hydrothermal springs may all be substantial sources of ${ }^{226} \mathrm{Ra}$ to the coastal ocean. ${ }^{226} \mathrm{Ra}$ was not useful as a tracer for calculating SGD at this site.

SGD at Stinson Beach is seasonally variable, with increased discharge occurring in the winter. Nutrient fluxes associated with SGD during winter months were large, even compared to nutrient loading associated with surface runoff in the area. The high degree of nutrient loading is consistent with previous studies at the site, which attribute the high concentrations of nitrogen and phosphate to the high density of septic systems used for wastewater treatment in the community. This study highlights the importance of 
groundwater quality protection in areas such as Stinson Beach and nearby Bolinas Lagoon, where SGD-associated nutrient flux can be a major component of the local marine biogeochemical budget.

Acknowledgments This research was supported by the National Sea Grant College Program of the US Department of Commerce's National Oceanic and Atmospheric Administration under NOAA Grant NA04OAR4170038, Project R/CZ-197, through the California Sea Grant College Program. The views expressed herein do not necessarily reflect the views of California Sea Grant. The authors acknowledge Karen Knee and Eric Foote for assistance in the field and/or suggestions for improving the manuscript. We acknowledge comments from the editor, associate editor, and two reviewers that improved the manuscript.

Open Access This article is distributed under the terms of the Creative Commons Attribution Noncommercial License which permits any noncommercial use, distribution, and reproduction in any medium, provided the original author(s) and source are credited.

\section{References}

Ataie-Ashtiani, B., R.E. Volker, and D.A. Lockington. 1999. Numerical and experimental study of seepage in unconfined aquifers with a periodic boundary condition. Journal of Hydrology 222: $165-184$.

Ataie-Ashtiani, B., R.E. Volker, and D.A. Lockington. 2001. Tidal effects on groundwater dynamics in unconfined aquifers. Hydrological Processes 15: 655-669.

Black, F.J., et al. 2009. Submarine groundwater discharge of total mercury and monomethylmercury to Central California coastal waters. Environmental Science \& Technology 43: 5652-5659.

Boehm, A.B., G.G. Shellenbarger, and A. Paytan. 2004. Groundwater discharge: Potential association with fecal indicator bacteria in the surf zone. Environmental Science \& Technology 38: 3558-3566.

Boehm, A.B., A. Paytan, G.G. Shellenbarger, and K.A. Davis. 2006. Composition and flux of groundwater from a California beach aquifer: Implications for nutrient supply to the surf zone. Continental Shelf Research 26: 269-282.

Bone, S.E., M.A. Charette, C.H. Lamborg, and M.E. Gonneea. 2007. Has submarine groundwater discharge been overlooked as a source of mercury to coastal waters? Environmental Science \& Technology 41: 3090-3095.

Burnett, W.C., et al. 2006. Quantifying submarine groundwater discharge in the coastal zone via multiple methods. The Science of the Total Environment 367: 498-543.

Caldwell, P.C. 2005. Validity of North Shore, Oahu, Hawaiian Islands surf observations. Journal of Coastal Research 21(6): $1127-1138$.

Charette, M.A., K.O. Buesseler, and J.E. Andrews. 2001. Utility of radium isotopes for evaluating the input and transport of groundwater-derived nitrogen to a Cape Cod estuary. Limnology and Oceanography 46: 465-470.

de Sieyes, N.R., K.M. Yamahara, B.A. Layton, E.H. Joyce, and A.B. Boehm. 2008. Submarine discharge of nutrient-enriched fresh groundwater at Stinson Beach, California is enhanced during neap tides. Limnology and Oceanography 53: 1434-1445.

Elsinger, R.J., and W.S. Moore. 1980. 226Ra behavior in the Pee Dee River-Winyah Bay estuary. Earth and Planetary Science Letters 48: 239-249.
Huettel, M., W. Ziebis, and S. Forster. 1996. Flow-induced uptake of particulate matter in permeable sediments. Limnology and Oceanography 41: 309-322.

Kim, G., and D.W. Hwang. 2002. Tidal pumping of groundwater into the coastal ocean revealed from submarine $\mathrm{Rn}-222$ and $\mathrm{CH} 4$ monitoring. Geophysical Research Letters 29: 1678.

Kim, G., W.C. Burnett, H. Dulaiova, P.W. Swarzenski, and W.S. Moore. 2001. Measurement of Ra-224 and Ra-226 activities in natural waters using a radon-in-air monitor. Environmental Science \& Technology 35: 4680-4683.

King, J.N., A.J. Mehta, and R.G. Dean. 2009. Generalized analytical model for benthic water flux forced by surface gravity waves. Journal of Geophysical Research-Oceans 114: C04004.

Komar, P.D. 1998. Beach processes and sedimentation, 543. Upper Saddle River: Prentice Hall.

Krest, J.M., and J.W. Harvey. 2003. Using natural distributions of short-lived radium isotopes to quantify groundwater discharge and recharge. Limnology and Oceanography 48: 290-298.

Li, L., D.A. Barry, F. Stagnitti, and J.Y. Parlange. 1999. Submarine groundwater discharge and associated chemical input to a coastal sea. Water Resources Research 35: 3253-3259.

Li, L., N. Cartwright, P. Nielsen, and D. Lockington. 2004. Response of coastal groundwater table to offshore storms. China Ocean Engineering 18: 423-431.

Libelo, E.L., and W.G. McIntyre. 1994. Effects of surface-water movement on seepage-meter measurements of flow through the sediment-water interface. Hydrogeology Journal 2: 49-54.

Longuet-Higgins, M.S. 1983. Wave set-up, percolation and undertow in the surf zone. Proceedings of the Royal Society of London A 390: 283-291.

Michael, H.A., A.E. Mulligan, and C.F. Harvey. 2005. Seasonal oscillations in water exchange between aquifers and the coastal ocean. Nature 436: 1145-1148.

Moore, W.S. 1996. Large groundwater inputs to coastal waters revealed by Ra-226 enrichments. Nature 380: 612-614.

Moore, W.S. 1997. High fluxes of radium and barium from the mouth of the Ganges-Brahmaputra river during low river discharge suggest a large groundwater source. Earth and Planetary Science Letters 150: 141-150.

Moore, W.S. 1999. The subterranean estuary: A reaction zone of ground water and sea water. Marine Chemistry 65: 111-125.

Moore, W.S. 2000a. Ages of continental shelf waters determined from Ra-223 and Ra-224. Journal of Geophysical Research-Oceans 105: 22117-22122.

Moore, W.S. 2000b. Determining coastal mixing rates using radium isotopes. Continental Shelf Research 20: 1993-2007.

Moore, W.S. 2003. Sources and fluxes of submarine groundwater discharge delineated by radium isotopes. Biogeochemistry 66: 75-93.

Moore, W.S., and R. Arnold. 1996. Measurement of ${ }^{223} \mathrm{Ra}$ and ${ }^{224} \mathrm{Ra}$ in coastal waters using a delayed coincidence counter. Journal of Geophysical Research 101: 1321-1329.

Paytan, A., et al. 2006. Submarine groundwater discharge: An important source of new inorganic nitrogen to coral reef ecosystems. Limnology and Oceanography 51: 343-348.

Pearson, J.M., I. Guymer, J.R. West, and L.E. Coates. 2002. Effect of wave height on cross-shore solute mixing. Journal of Waterway, Port, Coastal and Ocean Engineering 128: 1-11.

Philip Williams \& Associates. 2005. Bolinas Lagoon Ecosystem Restoration Feasibility Project. San Francisco: Philip Williams \& Associates.

Rama, J.F. Todd, J.L. Butts, and W.S. Moore. 1987. A new method for the rapid measurement of ${ }^{224} \mathrm{Ra}$ in natural waters. Marine Chemistry 22: 43-54. 
Rantz, S.E. 1982. Measurement and computation of streamflow: U.S. Geological Survey Water-Supply Paper 2175. 2 v., 631 p.

Rapaglia, J. 2005. Submarine groundwater discharge into Venice Lagoon, Italy. Estuaries 28: 705-713.

Ritter, J.R. 1973. Bolinas Lagoon, Marin County, California, summary of sedimentation and hydrology, 1967-69, 80. Menlo Park: USGS.

Robinson, C., L. Li, and D.A. Barry. 2007. Effect of tidal forcing on a subterranean estuary. Advances in Water Resources 30: 851-865.

Santos, I.R., W.C. Burnett, J. Chanton, B. Mwashote, I. Suryaputra, and T. Dittmar. 2008. Nutrient biogeochemistry in a Gulf of Mexico subterranean estuary and groundwater-derived fluxes to the coastal ocean. Limnology and Oceanography 53: 705718.
Santos, I.R., W.C. Burnett, J. Chanton, N. Dimova, and R.N. Peterson. 2009. Land or ocean?: Assessing the driving forces of submarine groundwater discharge at a coastal site in the Gulf of Mexico. Journal of Geophysical Research-Oceans 114: C04012.

Shellenbarger, G.G., S.G. Monismith, A. Genin, and A. Paytan. 2006. The importance of submarine groundwater discharge to the nearshore nutrient supply in the Gulf of Aqaba (Israel). Limnology and Oceanography 51: 1876-1886.

Stinson Beach County Water District. 1998. Stinson Beach Hydrologic Survey. Stinson Beach: Stinson Beach County Water District.

Taniguchi, M. 2002. Tidal effects on submarine groundwater discharge into the ocean. Geophysical Research Letters 29: 1561-1564.

Weight, W.D., and J.L. Sonderegger. 2001. Manual of applied field hydrogeology. New York: McGraw Hill. 